\title{
Current and future environmental impact of household solid waste management scenarios for a region of Brazil: carbon dioxide and energy analysis
}

\author{
Rafael Mattos Deus ${ }^{a, *}$, Rosane Aparecida Gomes Battistelle ${ }^{\text {, }}$ \\ Gustavo Henrique Ribeiro Silva ${ }^{\text {b }}$ \\ ${ }^{a}$ Department of Production Engineering, Faculty of Engineering of Bauru, São Paulo State University - FEB/UNESP, Av. Eng. Luiz Edmundo Carrijo Coube, \\ 14-01, CEP 17033 - 360 Bauru, SP, Brazil \\ ${ }^{\mathrm{b}}$ Department of Civil and Environmental Engineering, Faculty of Engineering of Bauru, São Paulo State University - FEB/UNESP, Av. Eng. Luiz Edmundo \\ Carrijo Coube, 14-01, CEP 17033 - 360 Bauru, SP, Brazil
}

\section{A R T I C L E I N F O}

\section{Article history:}

Received 2 February 2016

Received in revised form

24 May 2016

Accepted 25 May 2016

Available online 1 June 2016

\section{Keywords:}

Composting

Recycling

Integrated management

Solid waste

Environmental impact

Carbon dioxide

\begin{abstract}
A B S T R A C T
In Brazil, the largest share (51.4\%) of municipal solid waste is composed of organic matter; however composting is rarely used as a treatment technology. In 2008, only $3.8 \%$ of Brazilian municipalities had access to composting plants and about $11.6 \%$ of municipalities destined the municipal solid waste to recycling plants. This is only $1.4 \%$ of waste generated. Recycling and composting are key programs for municipalities to reduce environmental impact. Therefore, this study aims to evaluate the environmental impact of inserting a recycling, composting and integrated program in a region of Sao Paulo State, Brazil through the Waste Reduction Model method simulation of greenhouse gases emission (carbon dioxide equivalent and carbon equivalent) and energy use. The results show that recycling and composting can minimize the emission of greenhouse gases, reducing carbon dioxide and carbon equivalents, and promote energy savings. The best result is the integration of these techniques, which can reduce $78.8 \%$ of carbon dioxide and carbon equivalents and save $490.9 \%$ in energy versus baseline scenario. This study supports municipalities creating scenarios as a tool for planning and decision making to reach targets proposed by solid waste policies.
\end{abstract}

๑) 2016 Elsevier Ltd. All rights reserved.

\section{Introduction}

Solid waste management and planning is necessary for several industries (Ben-Awuah, 2015) and for municipalities as part of their infrastructures. This management requires financial planning, operation and maintenance (Alm, 2015). Solid waste has already been defined as a solid material with negative economic values. This makes the disposal cheaper than its use (Pichtel, 2005). Thus, it is understandable that waste has a positive value. It is important to all of society - industries, government, and all stakeholders. This importance can be analyzed through significant growth trends of studies on the theme "solid waste" worldwide (Yang et al., 2012) and in Brazil (Deus et al., 2015) as well as and also in the current

\footnotetext{
* Corresponding author.

E-mail addresses: rafaelmdeus@gmail.com (R.M. Deus), rosane@feb.unesp.br (R.A.G. Battistelle), gustavoribeiro@feb.unesp.br (G.H.R. Silva).
}

standards in several countries of the world. In Brazil, it is controlled with Law No. 12305 of August 2, 2010, regulated by Decree 7404 of December 23, 2010. Here, the National Policy on Solid Waste (NPSW) allowed new opportunities for business (Almeida Júnior et al., 2012) and lessons that improve services and enable environmentally friendly actions (Jabbour et al., 2014).

The main topics of NPSW involve good practices recommended by Massoud et al. (2003) such as: increased coverage of the collection service; closing of existing open dumps; introduction of sanitary landfills; system integration as recycling, composting and/ or incineration; introduction of service charges; private sector involvement; deliberate responsibilities evaluation of the various stakeholders including families and other users of services, local and national government authorities, NGOs, formal and informal enterprises as well as external agencies. This results in shared responsibility.

There are several techniques and tools that analyze solid waste management systems (Pires et al., 2011). One of them is the 
construction of scenarios that deal with complex and dynamic systems. In addition, being part of the planning process provides viable guidelines for decision-making. This technique uses ideas, structures and uncertainty to construct plausible scenarios and become test conditions for the business concepts and generate results (van der Heijden, 2002). This method deals with thinking through future decisions and policies and creates possible alternative organizational strategies in several contexts and organizations (Postma and Liebl, 2005) as well as strategic planning in waste management for municipalities (Spoerri et al., 2009). Thus, it was questioned what will be the environmental impact be within 15 years if a group of municipalities-most them size-adopt recycling, composting, or both versus continuing on the same trend? This question is important because it shows there are few studies involving small municipalities.

Therefore, this study aims to create, evaluate and compare the environmental impact of some scenarios including inserting a recycling, composting and integrated program in a region Sao Paulo State through a simulation of Greenhouse Gases (GHG) emission $\left(\mathrm{MTCO}_{2} \mathrm{E}\right.$ - metric tons of carbon dioxide equivalent, and MTCE metric tons of carbon equivalent) and energy use (BTU).

\section{Background}

This chapter is divided in four steps: 1) solid waste trends: presenting generation and composition of current and future trend on solid waste for world and Brazil; 2) Treatment and final disposal of solid waste: the fate of solid waste from Brazilian municipalities if they are treated or disposed without treatment on soil; 3) Brazilian National Policy on Solid Waste: Brazilian policy approaches to treatment and disposal of solid waste and where it cross with Zero Waste program; 4) Scenario as a tool for planning and decision making: a tool for municipalities managers. The model used in this study offers strategic planning to reach targets of current policy.

\subsection{Solid waste trends}

Waste and populations are growing. In Beijing, the population grew from 14.2 million in 2002 to 19.6 million in 2010, and the amount of municipal solid waste generated increased from 3.21 million tons in 2002 to 6.35 million tons in 2010. The percentage of organic waste increased from $45.8 \%$ in 2002 to $67.0 \%$ in 2010 (Wang and Wang, 2013). In Brazil, the amount of collected waste increased from $149,094.30$ ( $t$ /day) in 2000 to $183,481.50$ ( $t$ /day) in 2008 (Ministério do Meio Ambiente, 2012).

Fig. 1 presents the evolution of waste generation in the past and projections for the future in the world and its regions. The first scenario (SSP1) is $90 \%$ of the 7 billion of the world population live in cities, and development goals are achieved with reduced consumption of fossil fuels and environmentally aware citizens. In the second scenario (SSP2), there is a population of 9.5 billion people and $80 \%$ urbanization (intermediate scenario). In SSP3 scenario, there are 13.5 billion people and $70 \%$ live in cities. There is extreme poverty and moderate wealth. Many countries have high rates of population growth such as in Africa and Asia (Hoornweg et al., 2013). In Latin America, for intermediate scenario, the trend is that waste generation will grow strongly until 2025, and then grow less until 2070 and then stabilizes.

In Brazil, the composition of municipal solid waste is presented in Fig. 2. It is similar to that observed in other developing countries such as Mexico with the greatest share of organic matter (Buenrostro and Bocco, 2003). Developed and richer countries have less organic matter and more recycled materials, as observed in Portugal (Magrinho et al., 2006) and Greece (Erkut et al., 2008). The largest share of Brazilian waste is composed of organic matter (51.4\%) followed by materials that can be recycled (31.9\%). These are composed of glass, plastics, paper, steel and aluminum (Massukado et al., 2013). Solid waste composition is $46 \%$ organic, $17 \%$ paper, $10 \%$ plastic, 5\% glass, $4 \%$ metal and $18 \%$ other (Hoornweg and BhadaTata, 2012).

\subsection{Treatment and final disposal of solid waste}

Organic matter can be recovered by composting. This is low cost compared to other approaches including landfill disposal (Barreira et al., 2008). It also reduces emissions of greenhouse gas (GHG) (Vergara and Tchobanoglous, 2012). Friedrich and Trois (2016) comment if 71,793 tons of garden waste were sent to composting through turned windrows it will emit 13,282 tons of $\mathrm{CO}_{2}$ equivalent, however, if the same amount is not treated, then the emissions can reach 93,187 tons of $\mathrm{CO}_{2}$ equivalent.

Thus, composting is an environmentally appropriate type of treatment for organic waste, but Brazil does not use this treatment technology. In 2008, only $3.8 \%$ of the municipalities had composting plants (Table 1). In São Paulo, it was just 2.8\%. Compared with 2000 , there were an increase of around $35 \%$ of municipalities in 2008 with composting. However, the quantity of waste (Table 2) composted decreased around from $76 \%$ in $2000-2008$. This means is 6364.50 (4.5\%) to 1519.50 (0.8\%) (Instituto de Pesquisa Econômica Aplicada, 2012). Low and middle-income countries have a higher percentage of organic matter in their solid waste (up to $88 \%$ ) versus high-income countries ( $<56 \%$ ); however these developed countries have a higher amount of organic waste destined to composting (Hoornweg and Bhada-Tata, 2012).

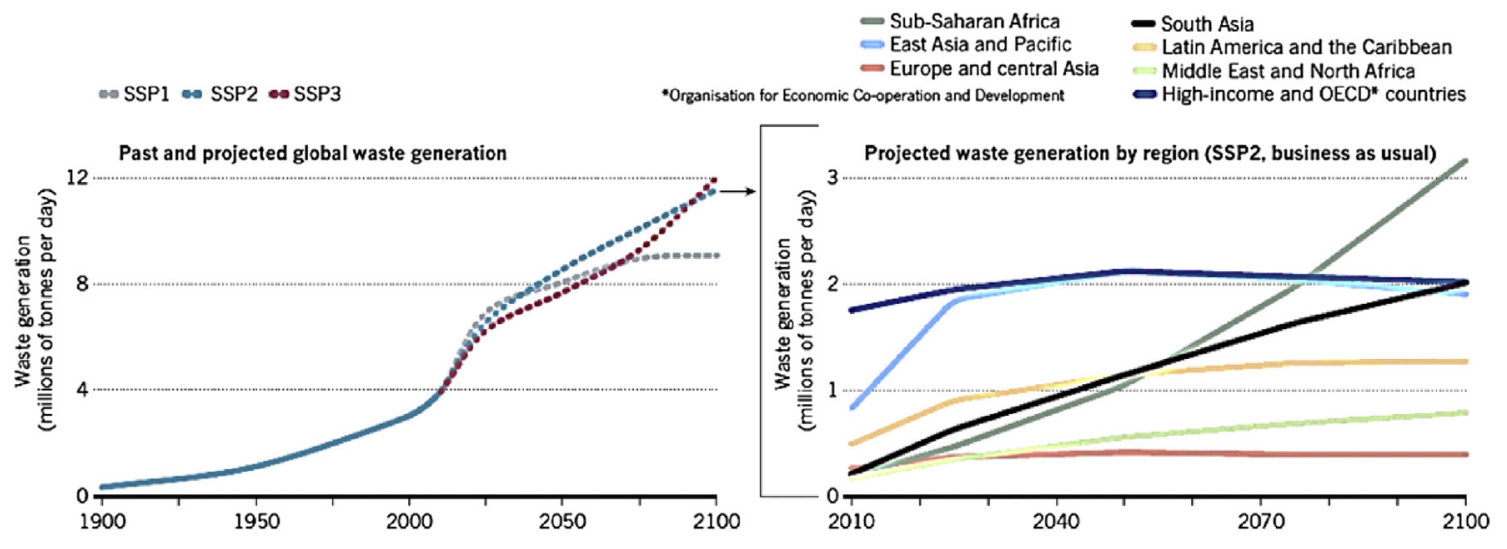

Fig. 1. Evolution of the generation of solid waste and its projections on three different scenarios. Source: Hoornweg et al. (2013). 

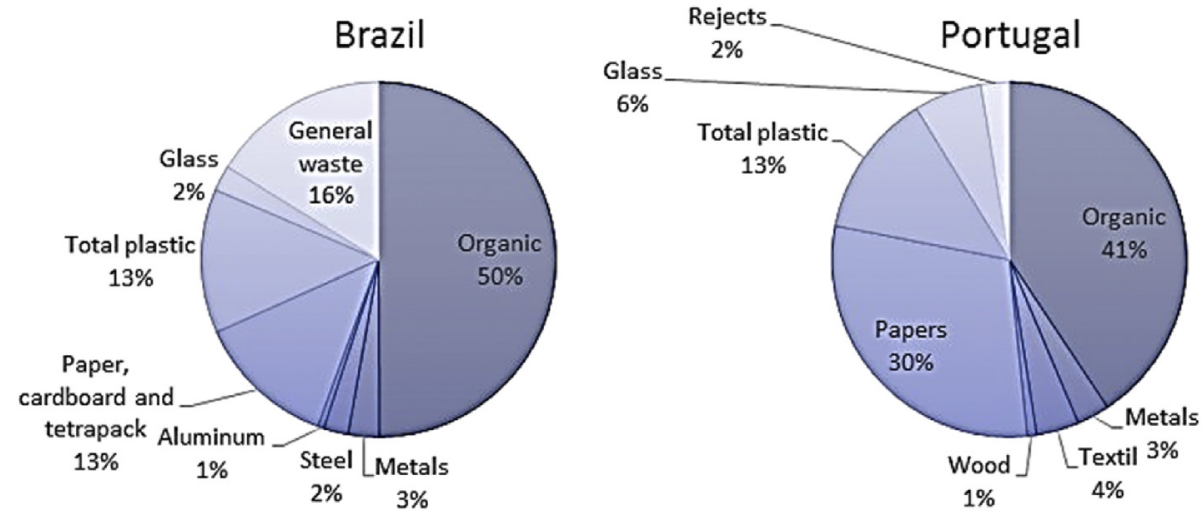

Mexico



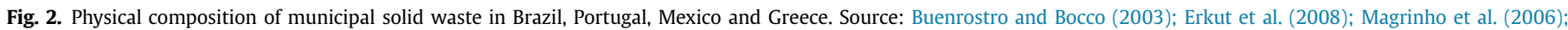
Massukado et al. (2013).

Table 1

Disposal of municipal solid waste by number of municipalities.

\begin{tabular}{|c|c|c|c|c|}
\hline \multirow[t]{2}{*}{ Final destination } & \multicolumn{2}{|c|}{$\begin{array}{l}\text { Number of } \\
\text { municipalities }\end{array}$} & \multicolumn{2}{|c|}{$\begin{array}{l}\text { Percentage of } \\
\text { municipalities }\end{array}$} \\
\hline & 2000 & 2008 & 2000 & 2008 \\
\hline Sanitary landfill & 810 & 1540 & 14.5 & 27.7 \\
\hline Controlled landfill & 1074 & 1254 & 19.3 & 22.5 \\
\hline Open dumps & 3763 & 2810 & 54.61 & 50.5 \\
\hline Composting plants & 157 & 211 & 2.8 & 3.8 \\
\hline Recycling plants & 248 & 643 & 4.5 & 11.6 \\
\hline Incineration plants & 176 & 134 & 3.2 & 0.6 \\
\hline Dumping in wetlands & 33 & 14 & 0.6 & 0.3 \\
\hline Not fixed places & 109 & - & 2 & - \\
\hline Others & 43 & 134 & 0.8 & 2.4 \\
\hline Total & 5565 & 5565 & - & - \\
\hline
\end{tabular}

Source: Instituto de Pesquisa Econômica Aplicada (2012).

Table 2

Daily amount of solid waste destined to different forms of final destination.

\begin{tabular}{|c|c|c|c|c|}
\hline \multirow[t]{2}{*}{ Final destination } & \multicolumn{2}{|l|}{2000} & \multicolumn{2}{|l|}{2008} \\
\hline & $\begin{array}{l}\text { Quantity } \\
\text { (ton/day) }\end{array}$ & $\%$ & Quantity (ton/day) & $\%$ \\
\hline Sanitary landfill & $49,614.50$ & 35.4 & $110,044.40$ & 58.3 \\
\hline Controlled landfill & $33,854.30$ & 24.2 & $36,673.20$ & 19.4 \\
\hline Open dumps & $45,484.70$ & 32.5 & $37,360.80$ & 19.8 \\
\hline Composting plants & 6364.50 & 4.5 & 1519.50 & 0.8 \\
\hline Recycling plants & 2158.10 & 1.5 & 2592.00 & 1.4 \\
\hline Incineration plants & 483.10 & 0.3 & 64.80 & $<0.1$ \\
\hline Dumping in wetlands & 228.10 & 0.2 & 35.00 & $<0.1$ \\
\hline Not fixed places & 877.30 & 0.6 & - & - \\
\hline Others & 1015.10 & 0.7 & 525.20 & 0.3 \\
\hline Total & $140,080.70$ & - & $188,814.90$ & - \\
\hline
\end{tabular}

Source: Instituto de Pesquisa Econômica Aplicada (2012).
In Brazil, data suggests poor management of organic waste. The National Policy on Solid Waste in Brazil encourages treatment of waste before final disposal (Brasil, 2010).

The NPSW, Law 12.305/2010, in its Article 3, defines environmentally final disposal as the waste disposal that include reuse, recycling, composting, recovery and energy recovery or other destinations that avoid damage or risks to public health and safety and minimize adverse environmental impacts. Moreover, Article 36 shows that the holder of solid waste management can implement a composting system for organic solid waste and can articulate with stakeholders the ways of using compost (Brasil, 2010).

Recycling is an environmentally appropriate type of treatment for recyclable waste, but is rare in Brazil. It has a great potential for reducing GHG emissions and saving energy. Friedrich and Trois (2016) affirm that increasing the recycling rate of $10 \%$ can save $6,54,276$ tons of $\mathrm{CO}_{2}$ equivalent. Menikpura et al. (2013) studied the life cycle of municipal solid waste and declared that recycling can save 92\% of total GHG. For Mahmoudkhani et al. (2014) recycling and composting scenario for a municipality solid waste management can significantly reduce GHG emissions and energy consumption.

In 2008 , about $11.6 \%$ of the municipalities had recycling plants (Table 1). From 2000 to 2008, there was an increase of $157 \%$ in municipalities with solid waste recycling. However, the quantity of waste (Table 2) destined for recycling increased by $20 \%$ from 2000 to 2008 . This means that 2158.10 (1.5\%) to 2592.00 ton/day (1.4\%). The total quantity of waste increased by $35 \%$. It was $140,080.70$ in 2000 and 188,814.90 ton/day in 2008 (Instituto de Pesquisa Econômica Aplicada, 2012). This result shows that recycling growth has not accompanied the general waste growth, so the share of amount destined to recycling decreased from $1.5 \%$ to $1.4 \%$. 
There are several factors that arrest the development and implementation of recycling programs such as government, educational, financial, administrative, and other factors (Troschinetz and Mihelcic, 2009). However, it is possible to implement successful programs that can achieve high levels of recycling as in Graz, Austria, where about $69 \%$ of household waste was recycled through a municipal program in 2004 and only 14\% was disposed in a landfill (Moczygemba and Smaka-Kincl, 2007). There are others examples of programs that reach high levels of recycling and composting, Table 3 presents the amount of municipal waste generated and the percentage of treatment of some European countries.

\subsection{Brazilian National Policy on Solid Waste}

One of the goals of the National Policy on Solid Waste, Law $12.305 / 2010$, in Brazil is the recycling and the encouraging of recycling industry. The law emphasizes the importance of recycling and encourages recycling to promote the use of raw materials and supplies derived from recyclable and recycled materials (Brasil, 2010).

The NPSW defines recycling as a process of transforming solid waste that involves its physical, physicochemical or biological changes or transforming it into new products (Brasil, 2010). This is the reason that recycling has great potential to reduce emissions of greenhouse gases, energy consumption and even water consumption due to the substitution of virgin materials, as observed by Fujii et al. (2014) on a recycling system for municipal solid waste. Mahmoudkhani et al. (2014) analyzed some scenarios with life cycle assessment, and Zaman (2014) measured performance of Zero Waste Index in a municipality.

It is important to highlight that NPSW has goal similar to Zero Waste program (Fig. 3), which is "designing and managing products and processes to systematically avoid and eliminate the volume and toxicity of waste and materials, conserve and recover all resources, and not burn or bury them" eliminating all disposal in soil (Zero Waste International Alliance, 2009).

\subsection{Scenario as a tool for planning and decision making}

Faced with a wide solid waste management tool, scenario building helps in the planning process to provide supports for decision-making (Pires et al., 2011). The scenarios technique is a prospective study that aims to describe alternative futures as a support in the decision and choice of the best alternative. Thus, this technique describes future possible or desirable situations as well as the entire process or path that connects to the initial situation (Buarque, 2003). Therefore the scenarios can contribute to real options on three main levels: 1 ) assist in the identification of future options; 2) help in decision time of implementing an option; 3) provide important information in the evaluation of real options (Cornelius et al., 2005).
Pollard and Hotho (2006) comment that the use of scenarios helps open new possibilities for strategic management analysis. This enables assessment of what could go wrong with following a strategy and a specific plan. Furthermore, the scenarios technique allows an approach for potential problem identification that can be treated with potential solutions.

Some authors divide the scenarios technique into two major groups: exploratory and desired or normative (Godet, 2000). The desired scenario reflects the best forecast, with reasonable and feasible description. This scenario is a plausible utopia that is has the best features and is technically and logically feasible. The desired scenario is the synthesis of the current reality. This is antithesis to the ideas and utopias of a society in relation to future (Buarque, 2003). This scenario builds alternative visions of desired future, but it also can build the most feared (Godet, 2000).

In scenarios development, Godet (2000) said that the main steps are: 1) identify the key variables of the objective of structural analysis; 2) analyze the games of stakeholders with important issues for the future, and 3 ) reduce uncertainties and choose the most probable scenarios. According to Börjeson et al. (2006), scenarios can also be divided according to use based on the following questions: What will happen? What can happen? and How will a specific target be achieved?

Some models for scenario building as a tool for planning and decision making are found in the literature including the Soil and Water Assessment Tool model used to quantify the impact of soil on land use (Boluwade and Madramootoo, 2015). The Life Cycle Assessment can evaluate complex systems including biogas generation (Rege et al., 2015) and solid waste management evaluation scenarios (Al-Salem et al., 2014). The Waste Reduction Model (WARM) created by the United States Environmental Protection Agency is one model widely used to determine the best options for reduction of greenhouse gas (GHG) emissions and energy consumption. Barros et al. (2013) used it to evaluate the impact of energy and the generation of greenhouse gases when implementing a selective collection program on a university campus. Brown (2016) emphasized that the WARM protocol focus on carbon emissions; Greene and Tonjes (2014) concluded that indicators like the WARM can provide important information for waste managers and policy makers to be helpful in performance and progress analysis. Lai et al. (2014) analyzed the environmental impact with WARM for the current and futures alternatives of a waste disposal program in the Region of Waterloo.

\section{Materials and methods}

This work addressed a normative/desired scenario of the type preservation for maximum environmental efficiency. The scenario consists of a set of plausible hypotheses that converge on the desires of society and government for the future. The process begins with the construction of a desired and ideal future hypothesis (Zero Waste) that will serve as a reference. A Zero Waste program

Table 3

Some European countries and their percentage of waste treatment in 2011.

\begin{tabular}{|c|c|c|c|c|c|c|}
\hline \multirow[t]{2}{*}{ Country } & \multirow{2}{*}{$\begin{array}{l}\text { Municipal waste generated, } \\
\text { kg per person }\end{array}$} & \multirow{2}{*}{$\begin{array}{l}\text { Total municipal waste treated, } \\
\text { kg per person }\end{array}$} & \multicolumn{4}{|c|}{ Municipal waste treated, \% } \\
\hline & & & Landfilled & Incinerated & Recycled & Composted \\
\hline Austria & 552 & 528 & 3 & 35 & 28 & 34 \\
\hline Belgium & 465 & 460 & 1 & 42 & 36 & 20 \\
\hline Germany & 597 & 597 & 1 & 37 & 45 & 17 \\
\hline Luxembourg & 687 & 687 & 15 & 38 & 27 & 20 \\
\hline Netherlands & 596 & 502 & 1 & 38 & 32 & 28 \\
\hline Sweden & 460 & 460 & 1 & 51 & 33 & 15 \\
\hline
\end{tabular}

Source: Adapted from Eurostat Press Office (2013). 


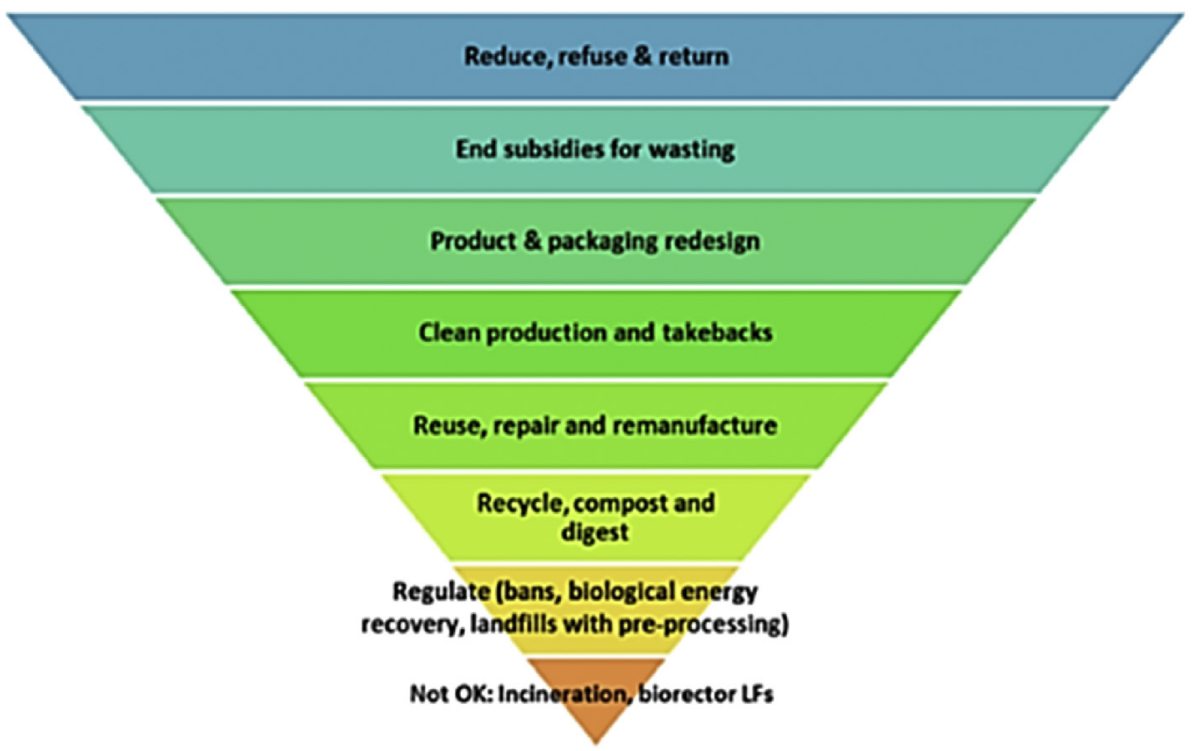

Fig. 3. Zero waste hierarchy according to the Zero Waste International Alliance. Source: Xevgenos et al. (2015).

provides an ideal development for municipalities on the issue of solid waste management even if there is a great difficulty to achieve their goals. This benefits from virgin materials substitution, energy savings, emissions saving and water savings (Zaman and Lehmann, 2013).

Understanding the concept of zero waste includes zero wastage, which means meaning a recycling rate of $100 \%$ and recovery of all resources from generated materials (Zaman and Lehmann, 2011). The ideal scenario was built from this starting with a target of 5\%$100 \%$ in 15 years ( $52.5 \%$ total) (Fig. 4 ).

The environmental impact including air impact translated in GHG emission and energy use by inserting composting (Scenario $\mathrm{C}$ ), recycling (Scenario $\mathrm{R}$ ) and integrated (Scenario $\mathrm{R}+\mathrm{C}$ ) program over 15 years starting with $5 \%$ and reaching $35 \%$ in the final year (20\% total) (Fig. 4) was questioned. The baseline scenario was compared to (current trends) the ideal scenario (Zero Waste program).

The municipalities studied here (Fig. 5) were selected because they share a private landfill in the city of Cachoeira Paulista. This having a composting and recycling plant in the same municipality would be more feasible. This scenario was used in the simulations.
Several models in the literature have determined the best options for reduction of greenhouse gas (GHG) emissions and energy consumption. In this study, the model was the Waste Reduction Model (WARM) version 12. The development of data of GHG emissions was according to the Life Cycle Assessment (LCA) using estimation techniques produced by GHG emission inventories (Environmental Protection Agency, 2006). The outputs are total $\mathrm{MTCO}_{2} \mathrm{E}$ (metric tons of carbon dioxide equivalent), total of MTCOE (metric tons of carbon equivalent) and Energy Use (millions of BTU).

The simulation of the environmental impact assessment used the gravimetric composition of municipal waste and the generation trend was presented in the Integrated Sanitation Plan of each municipality. Fig. 6 shows the general summary of this research method.

\section{Results and discussion}

The Integrated Regional Sanitation Plan of the region serves the municipalities of this study (Table 4). It highlights the important role of municipalities in the region in the form of cooperation and

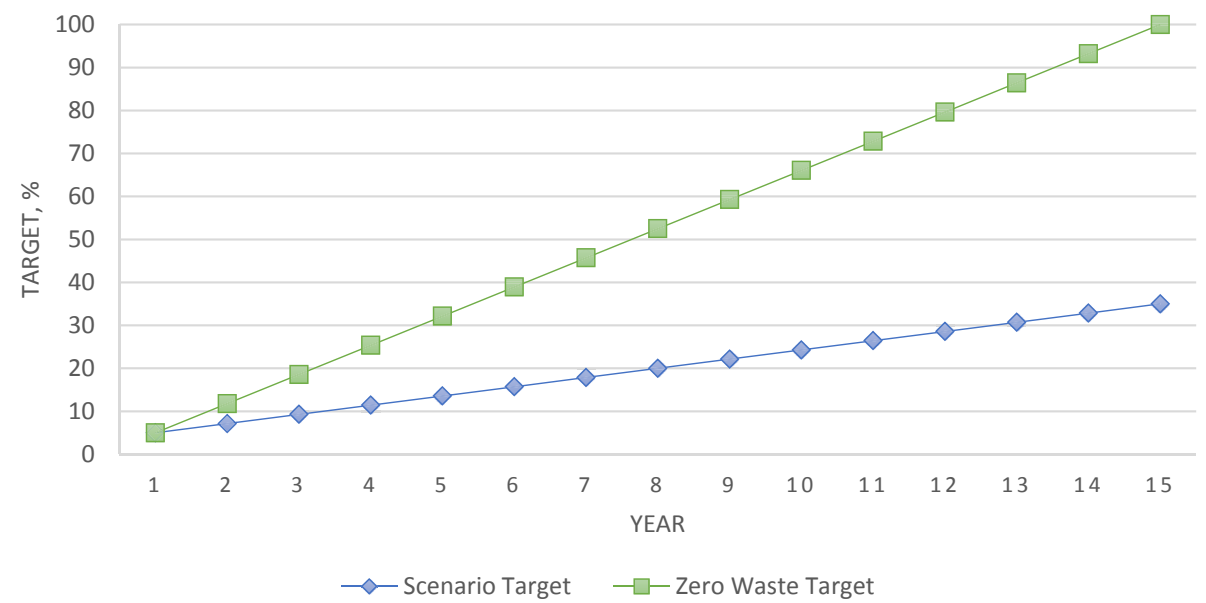

Fig. 4. Annual targets for the scenarios over 15 years. 


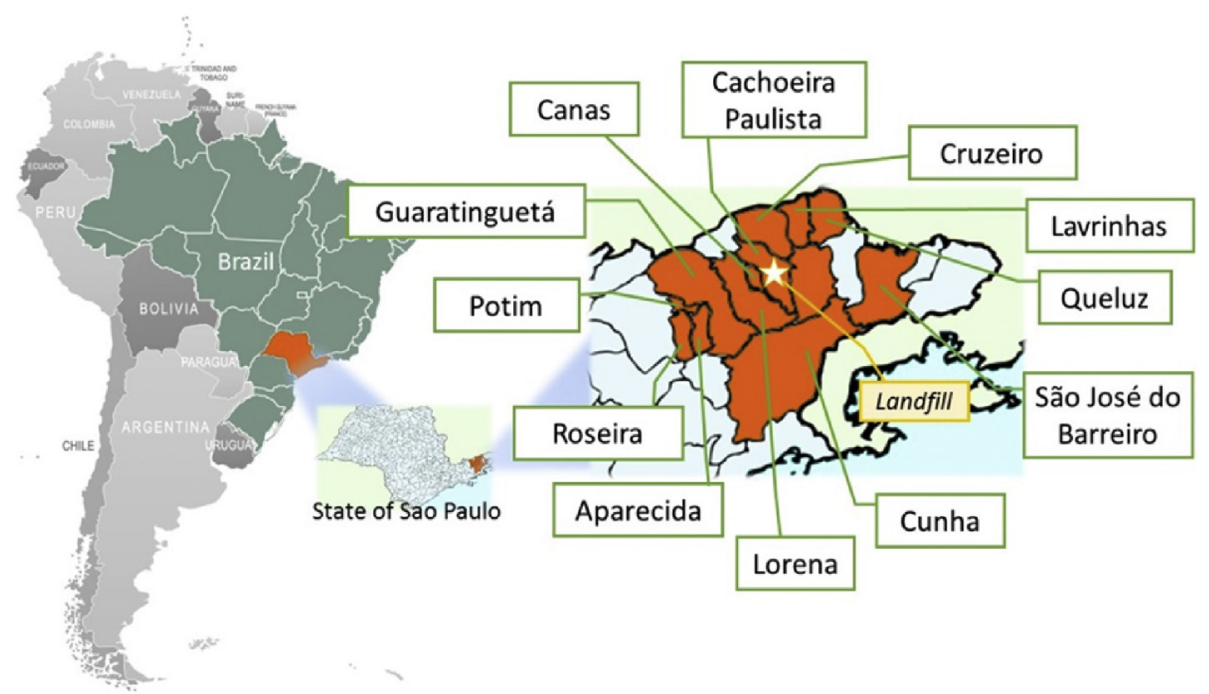

Fig. 5. Map indicating the municipalities that use the landfill in Cachoeira Paulista/SP, Brazil.


Fig. 6. General summary of the research method.

Table 4

Municipalities selected for study and their characteristics.

\begin{tabular}{|c|c|c|c|c|c|c|c|c|}
\hline City & $\begin{array}{l}\text { Population } \\
2010\end{array}$ & $\begin{array}{l}\text { Waste } \\
\text { production } \\
\text { (t/day) }\end{array}$ & $\begin{array}{l}\text { Has solid waste } \\
\text { integrated } \\
\text { management plan }\end{array}$ & $\begin{array}{l}\text { Has integrated } \\
\text { sanitation plan }\end{array}$ & $\begin{array}{l}\text { Has recycling } \\
\text { program* }\end{array}$ & $\begin{array}{l}\text { Has composting } \\
\text { program* }\end{array}$ & $\begin{array}{l}\text { VerdeAzul city program } \\
\text { score } 2014 \text { (rank) }\end{array}$ & $\begin{array}{l}\text { Average distance } \\
\text { from the landfill }(\mathrm{km})\end{array}$ \\
\hline Aparecida & 35,007 & 26 & No & Yes & No & No & $35.38\left(389^{\circ}\right)$ & 39.7 \\
\hline $\begin{array}{l}\text { Cachoeira } \\
\text { Paulista }\end{array}$ & 30,091 & 14.67 & No & Yes & No & No & $34.66\left(391^{\circ}\right)$ & 4 \\
\hline Canas & 4385 & 1.6 & No & Yes & No & No & - & 9.9 \\
\hline Cruzeiro & 77,009 & 36 & No & Yes & No & No & $37.38\left(371^{\circ}\right)$ & 20.1 \\
\hline Cunha & 21,866 & 5.53 & Yes & Yes & Yes & No & $1.74\left(586^{\circ}\right)$ & 83.4 \\
\hline Guaratinguetá & 112,072 & 73.33 & Yes & Yes & Yes & Yes & $1.78\left(585^{\circ}\right)$ & 35.6 \\
\hline Lavrinhas & 6590 & 2 & Yes & Yes & No & No & $1.39\left(589^{\circ}\right)$ & 26.9 \\
\hline Lorena & 82,537 & 43.3 & Yes & Yes & Yes & No & $48.11\left(318^{\circ}\right)$ & 15.8 \\
\hline Potim & 19,397 & 9 & No & Yes & No & No & - & 42.8 \\
\hline Queluz & 11,309 & 1.88 & No & Yes & No & No & $1.07\left(593^{\circ}\right)$ & 46.2 \\
\hline Roseira & 9599 & 5 & Yes & Yes & Yes & No & $19.19\left(442^{\circ}\right)$ & 49.8 \\
\hline $\begin{array}{c}\text { São José do } \\
\text { Barreiro }\end{array}$ & 4077 & 1.54 & No & Yes & No & No & $9.25\left(548^{\circ}\right)$ & 75.2 \\
\hline Silveiras & 5792 & 0.67 & No & Yes & Yes & No & $13.88\left(466^{\circ}\right)$ & 28.4 \\
\hline
\end{tabular}

Source: Adapted from CETESB (2016); IBGE (2010); * According to the Integrated Sanitation Plan.

partnerships for the construction of integrated regional solutions for solid waste management. It also creates regional units of waste sorting and composting in areas close to the cities of Cachoeira
Paulista, Tremembé, São José dos Campos and Guararema. There is installation of regional landfills in Cachoeira Paulista, Tremembé and Santa Isabel and the implementation of an Energy Recovery 
Unit to serve the Vale do Paraíba region (Secretaria do Meio Ambiente do Estado de São Paulo, 2014).

The municipalities involved are not certified in the VerdeAzul City program of State of São Paulo. They have low grades, and the higher of them is Lorena (48.11 points). This is far from the minimum of 80 points required for certificate municipalities. This program encourages and empowers local governments in the implementation and development of a strategic environmental agenda within 10 directives-one of them is solid waste (Secretaria do Meio Ambiente, 2014).

Characterization of the municipal region is presented in Table 5. There is waste collection in $99.33 \%$ of households, which is an important feature. However, Table 4, shows that of 13 municipalities, only 5 have some type of recycling program and only 1 has composting. While this is only tree pruning waste, it is the baseline for the 5\% target for recycling and composting (Fig. 4) depending on the scenario (Fig. 7).

The 12 municipalities are small ( $<100,000$ inhabitants), and this size often has more problems that are not addressed. They have less human, financial and technical resources at their disposal. These types of municipalities are often underserved in housing, transportation, piped water, waste disposal and other services (United Nations Population Fund, 2007).

The landfill is owned by the municipality of Cachoeira Paulista, which outsourced its operation to the private company VSA - Vale Soluções Ambientais Ltda. The license covers municipal solid waste IIA class (organic and non-inert), and their standard is quite satisfactory with scores of 9.4 for the Landfill Quality Index, which can reach up to 10 points (CETESB, 2013).

The construction of scenarios occurs after targets are achieved for global warming remediation. In 2009, Brazil was instituted the National Policy on Climate Change (NPCC) by Law No. 12.187/2009. The NPCC formalizes the voluntary commitment of Brazil to the UN Framework Convention on Climate Change about reduction of GHG

\section{Table 5}

Characterization of the municipal region.

\begin{tabular}{l}
\hline Indicator \\
\hline Preponderant use
\end{tabular}

Municipalities (34)

\begin{tabular}{ll} 
& Silveiras, Taubaté e Tremembé \\
Population & $\begin{array}{l}1,894,716 \text { inhabitants }(4.7 \% \text { of state of São } \\
\text { Paulo population) } \\
14,444 \mathrm{~km}^{2}\end{array}$ \\
Area & $\begin{array}{l}42 \text { billion reais ( } 42.82 \% \text { from the services } \\
\text { sector) }\end{array}$ \\
Added Value & $\begin{array}{l}9.33 \% \text { of urban permanent private } \\
\text { households }\end{array}$ \\
Average level of attendance by & $88 \%$ of the population served by sewage \\
regular garbage collection & collection service \\
Level of service for sewage & $59 \%$ of the population served by sewage \\
system collection & treatment \\
Level of service for sewage & - \\
treatment & \\
Certificates municipalities by & \\
VerdeAzul City program in & \\
2012 & \\
Municipality that presented to & Lorena \\
VerdeAzul City program the & \\
Solid Waste Integrated & \\
Management Plan in 2012 & \\
\hline
\end{tabular}

Source: Adapted from Secretaria do Meio Ambiente do Estado de São Paulo (2014). emission between $36.1 \%$ and $38.9 \%$ of projected emissions by 2020 (Brasil, 2009). The Brazilian National Plan on Climate Change is based on this policy and outlines a goal of increasing the recycling of solid waste to $20 \%$ by the year 2015 (Brasil, 2008).

Based on the goals and the feasibility that already occurs in some countries (Table 3), four alternative scenarios were developed beyond the current trajectory (Fig. 7). These check the environmental impact, and this impact quantifies emissions of greenhouse gases.

As shown in the baseline scenario (Table 6 and Figs. 7-10) of municipalities throughout the 15 years were analyzed. This will emit $369,662.8$ of $\mathrm{MTCO}_{2} \mathrm{E}, 100,817.1$ of MTCE and consume $531,086.8$ of M BTU. Compared to the other scenarios, the current trend is the worst.

As for Scenario C (Table 6 and Figs. 7-10) involves the composting of organic materials, and there will be emission of 279,654.7 $\mathrm{MTCO}_{2} \mathrm{E}$ and $76,269.5$ of MTCE. This represents a reduction compared to the baseline scenario of $24.3 \%$ for both. The energy consumption is 568,323.7 M BTU, which represents an increase compared to the baseline scenario of $7 \%$. The biggest advantage of this scenario is the lowest emission $\mathrm{MTCO}_{2} \mathrm{E}$ and MTCE and the disadvantage of this scenario is the energy consumption. This is due to the fact that the production of compounds-particularly with better quality-requires energy (Lou and Nair, 2009). However, composting can have a better costbenefit ratio in addition to moderate environmental impacts (Aye and Widjaya, 2006). In addition, Taheri et al. (2014) recommend composting together with landfill management. Of note, some are of low quality and require an efficient municipal program with proper separation and better use of technology to purify waste (Barreira et al., 2008).

Table 6 and Figs. 7-10 show that the recycling Scenario (R) of $20 \%$ of total recyclable waste is super in all aspects-especially in total energy. This is because recycling has great potential to reduce emissions of greenhouse gases, energy consumption and even water consumption due to the replacement of virgin raw materials, as confirmed by Friedrich and Trois (2016) study on municipal solid waste in a municipality of South Africa. Menikpura et al. (2013) also confirm in their study that recycling had so effective for GHG emissions reducing. This is supported by Zaman's (2014) Zero Waste research. Thus, in this scenario, there will be a total emission of $190,601.3 \mathrm{MTCO}_{2} \mathrm{E}$ and 51,982.2 of MTCE. It will avoid consumption of 2,113,276.1 M BTU of energy, which is a huge change from the baseline. This is a reduction compared to the baseline scenario of $48.4 \%, 48.4 \%$ and $497.9 \%$, respectively.

Lino et al. (2010) reported that the insertion of recyclable collection in Campinas city even if only $1 \%$ of the total can lead to energy savings of $3,486,722.2 \mathrm{kWh} /$ month. This equals a monthly energy consumption of 4000 houses.

The Scenario R + C (Table 6 and Figs. 7-10) shows that recycling and composting offer lower emissions of $\mathrm{MTCO}_{2} \mathrm{E}$ and MTCE due the combined use of recycling and composting similar to Mahmoudkhani et al. (2014). Therefore, this scenario will emit $100,593.2$ of $\mathrm{MTCO}_{2} \mathrm{E}$ and $27,434.5$ of MTCE, and will avoid the use of 2,076,039.0 M BTU. This represents a difference of $72.8 \%, 72.8 \%$ and $490.9 \%$ versus baseline. The integration of recycling and composting will decrease greenhouse gas emissions considerably versus baseline. The total energy is negative. It is slightly less than Scenario $\mathrm{R}$ because energy is used in composting.

The Ideal Scenario (Table 6 and Figs. 7-10) using recycling and composting (100\% at the end of 15 years) generates carbon credits. This credit is possible as occurred in Adelaide (Australia), San Francisco (USA) and Stockholm (Sweden) (Zaman and Lehmann, 2013). Therefore, this scenario avoids emission of $336,645.7$ $\mathrm{MTCO}_{2} \mathrm{E}$ and $91,812.5$ of MTCE. It will avoid energy use of 

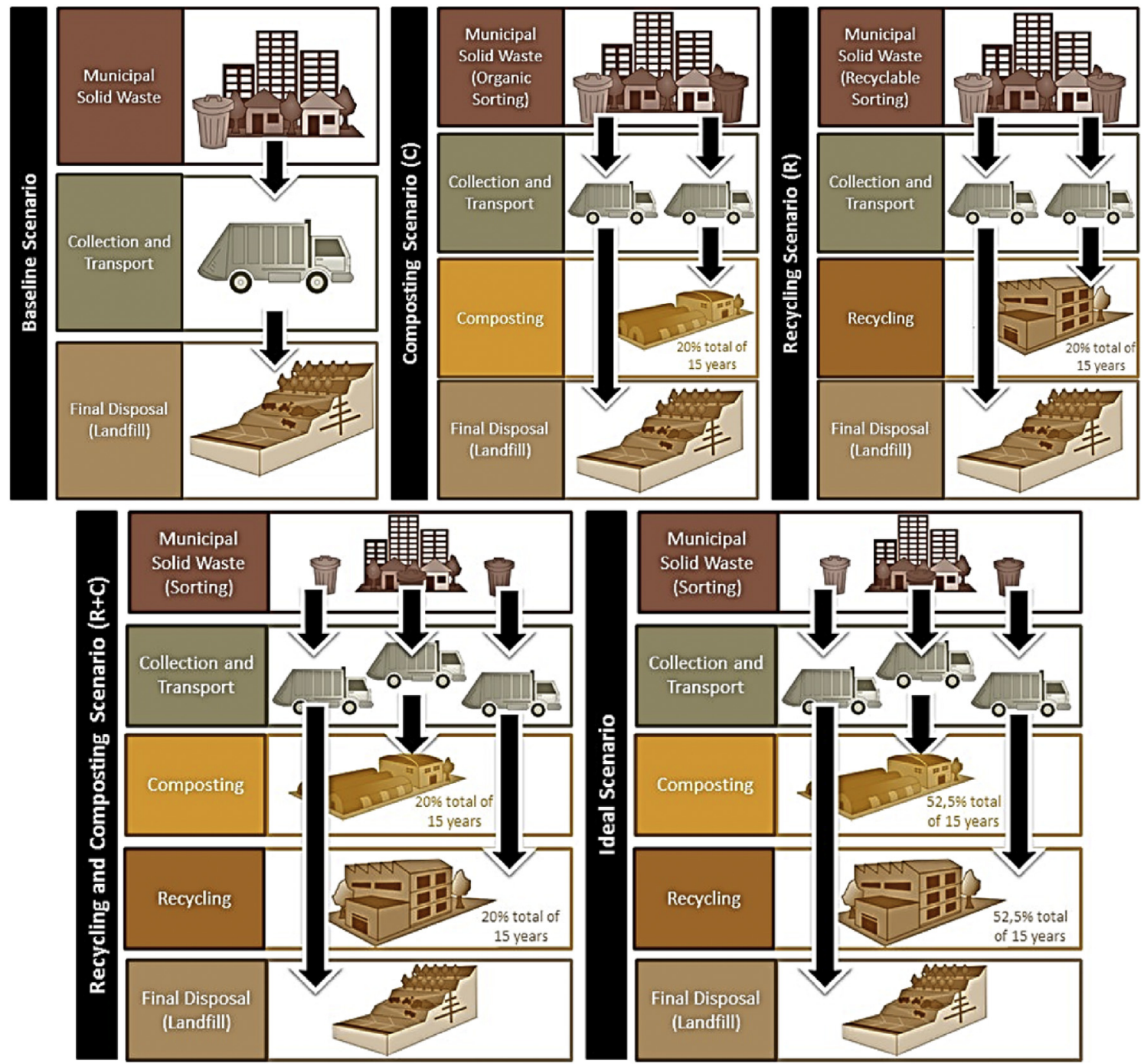

Fig. 7. Graphical schema of scenarios.

Table 6

Comparison of scenarios of Emission of greenhouse gases and energy use: total and percentage variation of alternative scenarios compared with baseline scenario (\%).

\begin{tabular}{|c|c|c|c|c|c|}
\hline & Baseline scenario & Scenario C & Scenario $\mathrm{R}$ & Scenario $\mathrm{R}+\mathrm{C}$ & Ideal scenario \\
\hline Total of $\mathrm{MTCO}_{2} \mathrm{E}$ & $369,662.8$ & $279,654.7(-24.3 \%)$ & $190,601.3(-48.4 \%)$ & $100,593.2(-72.8 \%)$ & $-336,645.7(-191.1 \%)$ \\
\hline $\begin{array}{l}\text { Total of energy } \\
\text { (millions of BTU) }\end{array}$ & $531,086.8$ & $568,323.7(7.0 \%)$ & $-2,113,276.1(-497.9 \%)$ & $-2,076,039.0(-490.9 \%)$ & $-6,312,631.7(-1288.6 \%)$ \\
\hline Total of MTCE & $100,817.1$ & $76,269.5(-24.3 \%)$ & $51,982.2(-48.4 \%)$ & $27,434.5(-72.8 \%)$ & $-91,812.5(-191.1 \%)$ \\
\hline
\end{tabular}

$\mathrm{MTCO}_{2} \mathrm{E}$ : metric tons of carbon dioxide equivalent; MTCOE: metric tons of carbon equivalent.

6,312,631.7 M BTU. This represents a difference $191.1 \%, 191 \%, 1 \%$ and $1288.6 \%$, versus baseline. It saves energy and reduces emissions. Virgin materials are substituted and water is saved (Zaman and Lehmann, 2013).

The National Policy on Solid Waste in Brazil encourages recycling and composting. Therefore, small Brazilian municipalities such as the case studied here should advance this target. Not only because it is the law, but also because it has integrated management that minimizes emissions of greenhouse gases and saves energy. Table 7 summarizes the environmental impacts of the landfill including composting, recycling and transportation. This is because it is related to the combustion of fossil fuel (Santos et al., 2014). This study focused more on the air dimension. While there are other aspects that can be analyzed, the GHG emissions are most critical to decision-making.

Most municipalities that use the Cachoeira Paulista landfill are small. They have limited financial and human resources (United Nations Population Fund, 2007). Thus, it is a necessary consortium and intermunicipal cooperation is needed to create recycling and composting programs. Other technical aspects have positive effects as recommended by the Department of the Environment of the State of São Paulo (Secretaria do Meio Ambiente do Estado de São Paulo, 2014). This is because this consortium allows a flexible management model, technical cooperation and joint achievements of activities. It maximizes efficient use of resources (Matos and Dias, 2011). Cooperation helps with 


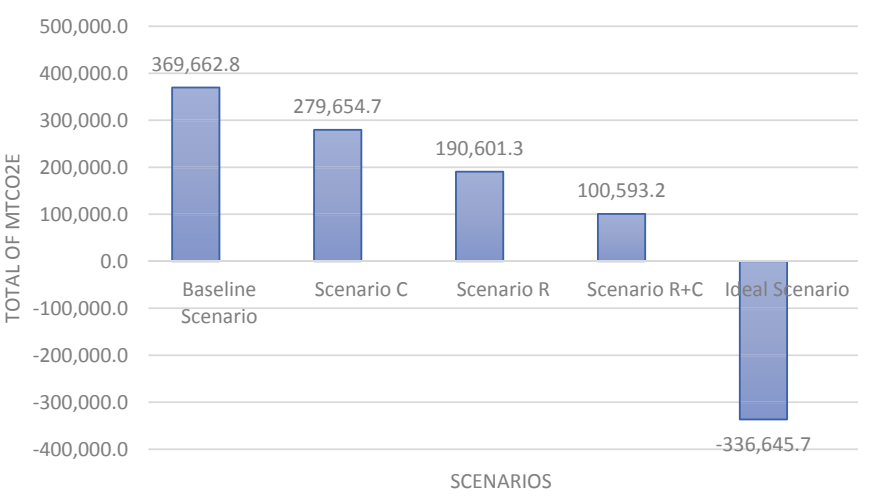

Fig. 8. Total emission of metric tons of carbon dioxide equivalent $\left(\mathrm{MTCO}_{2} \mathrm{E}\right)$ in each scenario.

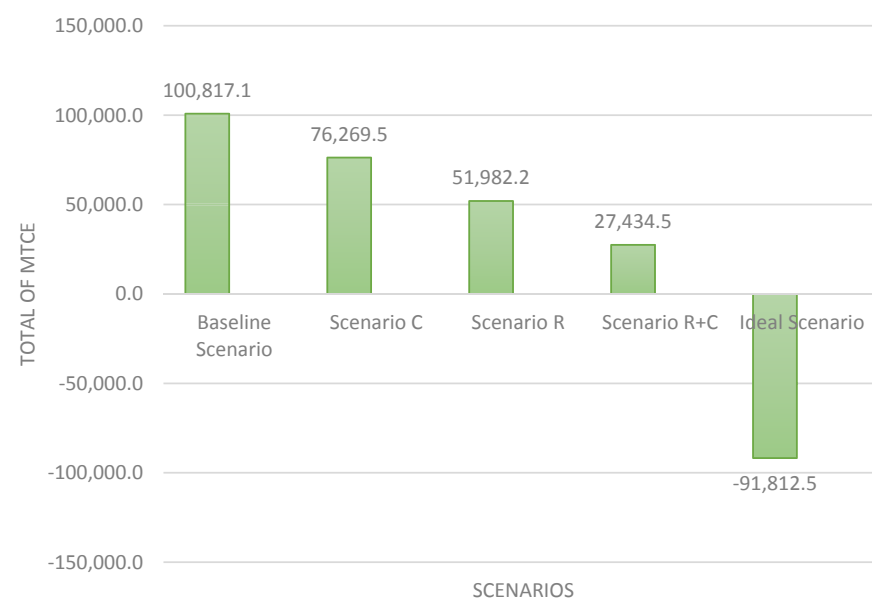

Fig. 9. Total emission of metric tons of carbon equivalent (MTCOE) in each scenario.

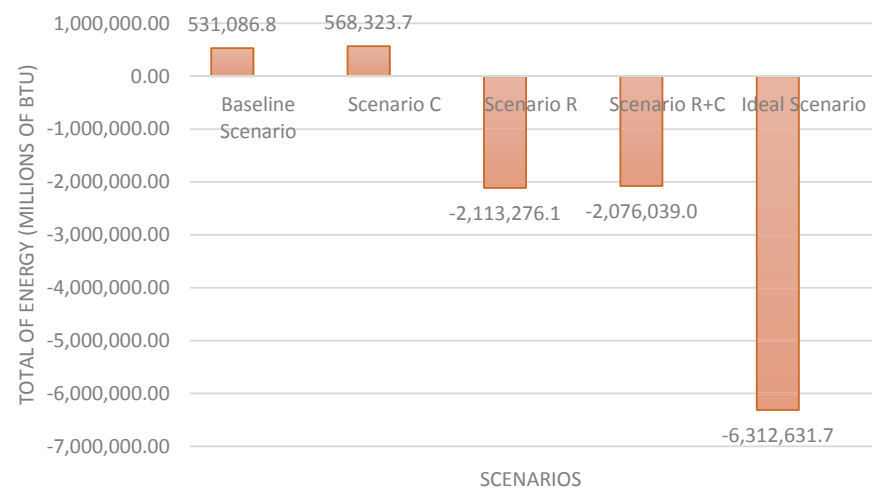

Fig. 10. Total energy consumption in millions of BTU in each scenario. recycling-especially these municipalities-because when the municipality does not even own a landfill, adding recycling is difficult (Usui et al., 2015).

\section{Conclusion}

The literature and this data suggests that organic matter is a major component of solid waste. Thus, composting is an important tool in municipal solid waste management as shown by the $\mathrm{Na}$ tional Policy on Solid Waste. It has an effective and positive environmental impact on $\mathrm{CO}_{2}$ and $\mathrm{C}$ equivalents, but not on energy consumption. The composting scenario for the municipalities of this study reduces GHG by $24.3 \%$ versus the current situation.

Therefore, it is important to integrate composting with others treatment tools for municipal solid waste management such as recycling. Because recycling has an effective and positive environmental impact, reducing the emission of greenhouse gases also saves energy because it reintegrates materials into the life cycle of products and thus reduces raw material extraction. This requires a high amount of energy. The scenario of recycling contributes to a reduction of $48.4 \%$ of GHG and $497.9 \%$ in energy savings compared to baseline scenario.

All alternative scenarios had positive impacts, but the scenario with the integrated management demonstrates that greater positive impacts will reduce GHG by $78.8 \%$ and save $490.9 \%$ in energy versus baseline. The current situation using just the landfill, which has great potential for greenhouse gas emissions, should be changed. However, this is limited by costs and social impacts (Aprilia and Tezuka, 2013).

Importantly, this approach can generate carbon credits. This would reduce GHG by $191 \%$ and save $1288.6 \%$ energy versus baseline. Although it is an almost utopian scenario, it should be considered an ideal target for total quality management.

Note also that recycling and composting also benefit the landfill because it increases its lifetime due to decreased waste destination. Therefore, the integrated management for municipal solid waste is the best scenario for minimizing negative environmental impacts. It should be considered in the decision-making of municipal management of solid waste.

Brazilian municipalities must elaborate their Solid Waste Integrated Management Plan based on NPSW and Zero Waste goals with targets of reduction, reuse, selective collection, and recycling/ composting reduce the waste disposed in soil. This plan uses scenario building as a tool to plan and decide on the generating support information and reaching targets.

One limitation of this study is that methane $\left(\mathrm{CH}_{4}\right)$ and nitrous oxide $\left(\mathrm{N}_{2} \mathrm{O}\right)$ emissions from compost are not included due the version of model used-this results in biogenic $\mathrm{CO}_{2}$ emissions because of decomposition. Biogenic $\mathrm{CO}_{2}$ is not counted as a GHG in the Inventory.

Future studies may also improve the scenarios approached here with economic aspects including capital costs to reach each

Table 7

Summary of environmental impacts of waste treatments.

\begin{tabular}{|c|c|c|c|c|}
\hline $\begin{array}{l}\text { Environmental } \\
\text { sink }\end{array}$ & Dumping/Landfill & Composting & Recycling & Transport \\
\hline Air & $\begin{array}{l}\mathrm{CO}_{2}, \mathrm{CH}_{4} \text {, odor, noise, VOCs, GHGs } \\
\left(\mathrm{CO} 2, \mathrm{CH}_{4}, \mathrm{~N}_{2} \mathrm{O}\right)\end{array}$ & $\begin{array}{l}\text { Odor, GHGs } \\
\text { (minor) }\end{array}$ & GHGs (minor) & $\mathrm{CO}_{2}, \mathrm{SO}_{2}, \mathrm{NO}_{\mathrm{x}}$, odor \\
\hline Soil & Heavy metals, organic compounds & Minor impact & Landfilling of residues & - \\
\hline Water & Leachate, heavy metals, organic compounds & Leachate & $\begin{array}{l}\text { Wastewater from } \\
\text { processing }\end{array}$ & $\begin{array}{l}\text { Fallout of atmospheric } \\
\text { pollutants (e.g., nitrate) }\end{array}$ \\
\hline
\end{tabular}

GHG, greenhouse gas; PCB, polychlorinated biphenyl; VOC, volatile organic compound.

Source: Adapted from Vergara and Tchobanoglous (2012). 
scenario and to verify the economic feasibility. Another important and necessary study is the anaerobic digestion modeling due to the huge biodegradable materials generation in Brazil and biogas collection from landfills for energy recovery.

\section{References}

Al-Salem, S.M., Evangelisti, S., Lettieri, P., 2014. Life cycle assessment of alternative technologies for municipal solid waste and plastic solid waste management in the Greater London area. Chem. Eng. J. 244, 391-402. http://dx.doi.org/10.1016/ j.cej.2014.01.066.

Alm, J., 2015. Financing urban infrastructure: knowns, unknowns, and a way forward. J. Econ. Surv. 29, 230-262. http://dx.doi.org/10.1111/joes.12045.

Almeida Júnior, A.F., Battistelle, R.A., Bezerra, B.S., Castro, R., 2012. Use of scrap tire rubber in place of SBS in modified asphalt as an environmentally correct alternative for Brazil. J. Clean. Prod. 33, 236-238. http://dx.doi.org/10.1016 j.jclepro.2012.03.039.

Aprilia, A., Tezuka, T., 2013. GHG emissions estimation from household solid waste management in Jakarta, Indonesia. J. Energy Power Eng. 7, 661-668.

Aye, L., Widjaya, E.R., 2006. Environmental and economic analyses of waste disposal options for traditional markets in Indonesia. Waste Manag. 26, 1180-1191. http://dx.doi.org/10.1016/j.wasman.2005.09.010.

Barreira, L.P., Philippi Junior, A., Rodrigues, M.S., Tenório, J.A.S., 2008. Physical analyses of compost from composting plants in Brazil. Waste Manag. 28, 1417-1422. http://dx.doi.org/10.1016/j.wasman.2007.05.023.

Barros, R.M., Filho, G.L.T., Moura, J.S., Pieroni, M.F., Vieira, F.C., Lage, L.R., Mohr, G.S. Bastos, A.S., 2013. Design and implementation study of a Permanent Selective Collection Program (PSCP) on a university campus in Brazil. Resour. Conserv. Recycl 80, 97-106. http://dx.doi.org/10.1016/j.resconrec.2013.09.005.

Ben-Awuah, E., 2015. Simultaneous production scheduling and waste management optimization for an oil sands application. J. Environ. Inf. 26, 80-90. http:// dx.doi.org/10.3808/jei.201500305.

Boluwade, A., Madramootoo, C., 2015. Determining the influence of land use change and soil heterogeneities on discharge, sediment and phosphorus. J. Environ. Inf. 25, 126-135. http://dx.doi.org/10.3808/jei.201500290.

Börjeson, L., Höjer, M., Dreborg, K.-H., Ekvall, T., Finnveden, G., 2006. Scenario types and techniques: towards a user's guide. Futures 38, 723-739. http://dx.doi.org/ 10.1016/j.futures.2005.12.002.

Brasil, 2010. Lei no 12.305, de 02 de agosto de 2010: Institui a Política Nacional de Resíduos Sólidos; altera a Lei no 9.605, de 12 de fevereiro de 1998. e dá outras providências, Brasília, Brasil.

Brasil, 2009. Lei no 12.187, de 29 de dezembro de 2009. Institui a Política Nacional sobre Mudança do Clima - PNMC e dá outras providências, Brasil.

Brasil, 2008. Plano Nacional sobre Mudança do Clima - PNMC Brasil. Comitê Interministerial sobre Mudança do Clima, Brasília.

Brown, S., 2016. Greenhouse gas accounting for landfill diversion of food scraps and yard waste. Compost Sci. Util. 24, 11-19. http://dx.doi.org/10.1080/ 1065657X.2015.1026005.

Buarque, S.C., 2003. Metodologia e técnicas de construção de cenários. IPEA, Brasília.

Buenrostro, O., Bocco, G., 2003. Solid waste management in municipalities in Mexico: goals and perspectives. Resour. Conserv. Recycl 39, 251-263. http:// dx.doi.org/10.1016/S0921-3449(03)00031-4.

CETESB, 2016. Mapa UGRHIS [WWW Document]. URL. http://licenciamento.cetesb. sp.gov.br/mapa_ugrhis/mapa.php (accessed 1.14.16).

CETESB, 2013. Inventário estadual de resíduos sólidos domiciliares 2012. CETESB, São Paulo.

Cornelius, P., Van de Putte, A., Romani, M., 2005. Three decades of scenario planning in shell. Calif. Manage. Rev. 48, 92-109.

Deus, R.M., Battistelle, R.A.G., Silva, G.H.R., 2015. Resíduos sólidos no Brasil: contexto, lacunas e tendências. Eng. Sanit. Ambient 20, 685-698. http://dx.doi.org 10.1590/S1413-41522015020040129347.

Environmental Protection Agency, 2006. User's Guide for WARM [WWW Document]. User's Guid. WARM. URL. http://epa.gov/epawaste/conserve/tools/ warm/Warm_UsersGuide.html (accessed 4.13.14).

Erkut, E., Karagiannidis, A., Perkoulidis, G., Tjandra, S.A., 2008. A multicriteria facility location model for municipal solid waste management in North Greece. Eur. J. Oper. Res. 187, 1402-1421. http://dx.doi.org/10.1016/j.ejor.2006.09.021.

Eurostat Press Office, 2013. In 2011, 40 \% of Treated Municipal Waste Was Recycled or Composted, up from $27 \%$ in 2001.

Friedrich, E., Trois, C., 2016. Current and future greenhouse gas (GHG) emissions from the management of municipal solid waste in the eThekwini Municipality - South Africa. J. Clean. Prod. 112, 4071-4083. http://dx.doi.org/10.1016 j.jclepro.2015.05.118.

Fujii, M., Fujita, T., Ohnishi, S., Yamaguchi, N., Yong, G., Park, H.-S., 2014. Regional and temporal simulation of a smart recycling system for municipal organic solid wastes. J. Clean. Prod. 78, 208-215. http://dx.doi.org/10.1016/ j.jclepro.2014.04.066.

Godet, M., 2000. The art of scenarios and strategic planning. Technol. Forecast. Soc Change 65, 3-22. http://dx.doi.org/10.1016/S0040-1625(99)00120-1.

Greene, K.L., Tonjes, D.J., 2014. Quantitative assessments of municipal waste management systems: using different indicators to compare and rank programs in New York State. Waste Manag. 34, 825-836. http://dx.doi.org/10.1016/ j.wasman.2013.12.020

Hoornweg, D., Bhada-Tata, P., 2012. What a Waste: a Global Review of Solid Waste Management. World Bank, Washington DC. World Bank, Washington.

Hoornweg, D., Bhada-Tata, P., Kennedy, C., 2013. Environment: waste production must peak this century. Nature 502, 615-617. http://dx.doi.org/10.1038/502615a.

IBGE, 2010. Censo Demográfico 2010 [WWW Document]. URL. http://censo2010. ibge.gov.br/.

Instituto de Pesquisa Econômica Aplicada, 2012. Diagnóstico dos Resíduos Sólidos Urbanos. IPEA, Brasília.

Jabbour, A.B.L. de S., Jabbour, C.J.C., Sarkis, J., Govindan, K., 2014. Brazil's new national policy on solid waste: challenges and opportunities. Clean Technol. Environ. Policy 16, 7-9. http://dx.doi.org/10.1007/s10098-013-0600-z.

Lai, K., Li, L., Mutti, S., Staring, R., Taylor, M., Umali, J., Pagsuyoin, S., 2014. Evaluation of waste reduction and diversion as alternatives to landfill disposal. In: 2014 Systems and Information Engineering Design Symposium (SIEDS). IEEE, pp. 183-187. http://dx.doi.org/10.1109/SIEDS.2014.6829877.

Lino, F.A.M., Bizzo, W.A., da Silva, E.P., Ismail, K.A.R., 2010. Energy impact of waste recyclable in a Brazilian metropolitan. Resour. Conserv. Recycl 54, 916-922. http://dx.doi.org/10.1016/j.resconrec.2010.01.010.

Lou, X.F., Nair, J., 2009. The impact of landfilling and composting on greenhouse gas emissions: a review. Bioresour. Technol. 100, 3792-3798. http://dx.doi.org/ 10.1016/j.biortech.2008.12.006

Magrinho, A., Didelet, F., Semiao, V., 2006. Municipal solid waste disposal in Portugal. Waste Manag. 26, 1477-1489.

Mahmoudkhani, R., Valizadeh, B., Khastoo, H., 2014. Greenhouse Gases Life Cycle Assessment (GHGLCA) as a decision support tool for municipal solid waste management in Iran. J. Environ. Heal. Sci. Eng. 12,1-7. http://dx.doi.org/10.1186/ 2052-336X-12-71.

Massoud, M., El-Fadel, M., Abdel Malak, A., 2003. Assessment of public vs private MSW management: a case study. J. Environ. Manage 69, 15-24. http:// dx.doi.org/10.1016/S0301-4797(03)00104-X.

Massukado, L.M., Milanez, B., Luedemann, G., Hargrave, J., 2013. Diagnóstico da Gestão de Resíduos Sólidos Urbanos no Brasil: uma análise pós PNSB 2008ênfase na destinação final e nos resíduos orgânicos. Rev. DAE 22-33.

Matos, F., Dias, R., 2011. A gestão de resíduos sólidos e a formaçao de consórcios intermunicipais. Rev. em Agronegócios Meio Ambient 4, 501-519.

Menikpura, S.N.M., Sang-Arun, J., Bengtsson, M., 2013. Integrated solid waste management: an approach for enhancing climate co-benefits through resource recovery. J. Clean. Prod. 58, 34-42. http://dx.doi.org/10.1016/ j.jclepro.2013.03.012.

Ministério do Meio Ambiente, 2012. Plano nacional de resíduos sólidos. MMA, Brasília.

Moczygemba, E., Smaka-Kincl, V., 2007. 69 per cent recycling rate for waste management in Graz, Austria. Manag. Environ. Qual. An Int. J. 18, 126-136. http:// dx.doi.org/10.1108/14777830710725803.

Pichtel, J., 2005. Waste Management Practices: Municipal, Hazardous, and Industrial. Taylor \& Francis, Boca Raton.

Pires, A., Martinho, G., Chang, N.-B., 2011. Solid waste management in European countries: a review of systems analysis techniques. J. Environ. Manage 92, 1033-1050. http://dx.doi.org/10.1016/j.jenvman.2010.11.024.

Pollard, D., Hotho, S., 2006. Crises, scenarios and the strategic management process. Manag. Decis. 44, 721-736. http://dx.doi.org/10.1108/00251740610673297.

Postma, T.J.B.M., Liebl, F., 2005. How to improve scenario analysis as a strategic management tool? Technol. Forecast. Soc. Change 72, 161-173. http:/ dx.doi.org/10.1016/j.techfore.2003.11.005.

Rege, S., Arenz, M., Marvuglia, A., Vázquez-Rowe, I., Benetto, E., Igos, E., Koster, D., 2015. Quantification of agricultural land use changes in consequential Life Cycle Assessment using mathematical programming models following a partial equilibrium approach. J. Environ. Inf. 26, 121-139. http://dx.doi.org/10.3808/ jei.201500304.

Santos, M.F.N., Battistelle, R.A.G., Bezerra, B.S., Varum, H.S.A., 2014. Comparative study of the life cycle assessment of particleboards made of residues from sugarcane bagasse (Saccharum spp.) and pine wood shavings (Pinus elliottii). J. Clean. Prod. 64, 345-355. http://dx.doi.org/10.1016/j.jclepro.2013.06.039.

Secretaria do Meio Ambiente, 2014. Município VerdeAzul [WWW Document]. URL. http://www.ambiente.sp.gov.br/municipioverdeazul/ (accessed 01.17.15).

Secretaria do Meio Ambiente do Estado de São Paulo, 2014. Plano de Resíduos Sólidos do Estado de São Paulo, first ed. SMA, São Paulo.

Spoerri, A., Lang, D.J., Binder, C.R., Scholz, R.W., 2009. Expert-based scenarios for strategic waste and resource management planning-C\&D waste recycling in the Canton of Zurich. Switz. Resour. Conserv. Recycl 53, 592-600. http:// dx.doi.org/10.1016/j.resconrec.2009.04.011.

Taheri, M., Gholamalifard, M., Ghazizade, M.J., Rahimoghli, S., 2014. Environmental impact assessment of municipal solid waste disposal site in Tabriz, Iran using rapid impact assessment matrix. Impact Assess. Proj. Apprais 32, 162-169. http://dx.doi.org/10.1080/14615517.2014.896082.

Troschinetz, A.M., Mihelcic, J.R., 2009. Sustainable recycling of municipal solid waste in developing countries. Waste Manag. 29, 915-923. http://dx.doi.org/ 10.1016/j.wasman.2008.04.016

United Nations Population Fund, 2007. The State of the World Population 2007: Unleashing the Potential of Urban Growth. UNFPA, New York, ISBN 978-089714-807-8.

Usui, T., Kakamu, K., Chikasada, M., 2015. To introduce recycling or not: a panel data analysis in Japan. Resour. Conserv. Recycl 101, 84-95. http://dx.doi.org/10.1016/ j.resconrec.2015.05.006. 
van der Heijden, K., 2002. Scenarios: the Art of Strategic Conversation. John Wiley \& Sons, Chichester.

Vergara, S.E., Tchobanoglous, G., 2012. Municipal solid waste and the environment: a global perspective. Annu. Rev. Environ. Resour. 37, 277-309. http://dx.doi.org/ 10.1146/annurev-environ-050511-122532.

Wang, H., Wang, C., 2013. Municipal solid waste management in Beijing: characteristics and challenges. Waste Manag. Res. 31, 67-72. http://dx.doi.org/ 10.1177/0734242X12468199.

Xevgenos, D., Papadaskalopoulou, C., Panaretou, V., Moustakas, K., Malamis, D., 2015. Success stories for recycling of MSW at municipal Level: a review. Waste Biomass Valorization 6, 657-684. http://dx.doi.org/10.1007/s12649-015-9389-9.

Yang, L., Chen, Z., Liu, T., Gong, Z., Yu, Y., Wang, J., 2012. Global trends of solid waste research from 1997 to 2011 by using bibliometric analysis. Scientometrics 96,
133-146. http://dx.doi.org/10.1007/s11192-012-0911-6.

Zaman, A.U., 2014. Measuring waste management performance using the "Zero Waste Index": the case of Adelaide, Australia. J. Clean. Prod. 66, 407-419. http:/ dx.doi.org/10.1016/j.jclepro.2013.10.032.

Zaman, A.U., Lehmann, S., 2013. The zero waste index: a performance measuremen tool for waste management systems in a "zero waste city." J. Clean. Prod. 50, 123-132. http://dx.doi.org/10.1016/j.jclepro.2012.11.041.

Zaman, A.U., Lehmann, S., 2011. Urban growth and waste management optimization towards "zero waste city." City, Cult. Soc. 2, 177-187. http://dx.doi.org/10.1016 j.ccs.2011.11.007.

Zero Waste International Alliance, 2009. ZW Definition [WWW Document]. URL. http://zwia.org/standards/zW-definition/ (accessed 1.17.16). 